WPS3616

\title{
Would Multilateral Trade Reform Benefit Sub-Saharan Africans?
}

\author{
Kym Anderson, Will Martin and Dominique van der Mensbrugghe
}

\author{
World Bank \\ 1818 H Street NW \\ Washington DC 20433 \\ kanderson@worldbank.org \\ wmartin1@worldbank.org \\ dvandermensbrugg@worldbank.org
}

\begin{abstract}
World Bank Policy Research Working Paper 3616, June 2005
The Policy Research Working Paper Series disseminates the findings of work in progress to encourage the exchange of ideas about development issues. An objective of the series is to get the findings out quickly, even if the presentations are less than fully polished. The papers carry the names of the authors and should be cited accordingly. The findings, interpretations, and conclusions expressed in this paper are entirely those of the authors. They do not necessarily represent the view of the World Bank, its Executive Directors, or the countries they represent. Policy Research Working Papers are available online at http://econ.worldbank.org.
\end{abstract}

Presented at the UNECA/ADB/UNDP/SADC Workshop on Economic Partnership Agreements, Maputo, Mozambique, 4-5 April 2005 and the TIPS seminar on Doha's Impact on Trade, Welfare and Poverty, Pretoria, South Africa, 6 April 2005. The authors are grateful for discussions with Arvind Panagariya on this issue, for helpful comments from Tom Hertel and other project participants plus Larry Hinkle and Patrick Osakwe, for tariff-cutting data from CEPII staff in Paris (with special thanks to David Laborde), and for funding from the UK's Department for International Development. The views expressed are the authors' alone. This paper is a product of the World Bank's DfID-funded project on Agricultural Trade Reform and the Doha Development Agenda. 


\begin{abstract}
This paper examines whether the Sub-Saharan African economies could gain from multilateral trade reform in the presence of trade preferences. The World Bank's LinKAGE model of the global economy is employed to examine the impact first of current trade barriers and agricultural subsidies, and then of possible outcomes from the WTO's Doha round. The results suggest moving to free global merchandise trade would boost real incomes in Sub-Saharan Africa proportionately more than in other developing countries or in high-income countries, despite a terms of trade loss in parts of the region. Farm employment and output, the real value of agricultural and food exports, the real returns to farm land and unskilled labor, and real net farm incomes would all rise in the region, thereby alleviating poverty. Results for a Doha partial liberalization of both agricultural and non-agricultural trade take the region only a small part of the way towards those desirable outcomes.
\end{abstract}

JEL codes: C68, D58, F13, F17, O55, Q17

Key words: Trade policy, WTO, multilateral negotiations, computable general equilibrium, SubSaharan Africa

\title{
Contact author:
}

Kym Anderson

Development Research Group

The World Bank, Mailstop MC3-303

1818 H Street NW

Washington DC 20433 USA

Phone +1 2024733387

Fax $\quad+12025221159$

kanderson@worldbank.org 


\title{
Would Multilateral Trade Reform Benefit Sub-Saharan Africans?
}

\author{
Kym Anderson, Will Martin and Dominique van der Mensbrugghe
}

\section{Introduction}

According to Chen and Ravallion (2004), Africa now accounts for one-third of the world's people living on less than $\$ 1$ a day (up from one-tenth two decades ago). The vast majority of those people are dependent on agriculture for their livelihood, and for much of the food they eat. Raising agricultural productivity in Sub-Saharan Africa (SSA) is one possible way to alleviate people's poverty. ${ }^{1}$ Another possibility is through cuts to agricultural (and textile) protection in rich countries, for example via the World Trade Organization's Doha Development Agenda. While a comprehensive multilateral trade reform should boost economic growth and thereby reduce poverty in general, ${ }^{2}$ Panagariya (2004) has questioned whether this applies to SSA countries in particular. He cites two reasons. One is that those countries that are net importers of food would face higher

1 On prospects for doing that using new biotechnologies, see Anderson and Jackson (2005).

2 For recent reviews of the literature on the links between trade liberalization, economic growth and poverty alleviation, see for example Winters (2002, 2004), Winters, McCulloch and McKay (2004), Dollar and Kraay (2004), Anderson (2004) and DTI (2004). Rodrigeuz and Rodrik (2001) examine a number of studies linking trade and growth and claim the results they surveyed are not robust. However, in a more recent study that revisits the Sachs and Warner (1995) data and then provides new time-series evidence, Wacziarg and Welch (2003) show that dates of trade liberalization do characterize breaks in investment and GDP growth rates. Specifically, for the 19501998 period, countries that have liberalized their trade (raising their trade-to-GDP ratio by an average of 5 percentage points) have enjoyed on average 1.5 percentage points higher GDP growth compared with their prereform rate. 
food import prices. The other is that those countries that are net exporters of farm (and textile) products already enjoy duty-free access to the key markets of Europe and North America under various trade preference arrangements, so cuts to most-favoured-nation (MFN) import tariffs by rich countries would erode SSA preference margins. Either way, SSA economies could be worse off. A third possible way in which SSA terms of trade could deteriorate is through export expansion of a small number of similar products following the region's own trade liberalization, should it choose to participate in a multilateral reform.

This paper seeks to address the empirical question implicit in that critique. It does so using the World Bank's LiNKAGE model of the global economy and its new global trade and protection database that explicitly includes, for the first time, the non-reciprocal tariff preferences enjoyed by developing and especially least developed countries, including in SSA. The model is employed to examine the impact on markets, welfare and poverty in SSA first of current agricultural trade distortions and subsidies and then also non-agricultural trade distortions, before analyzing possible outcomes from the Doha round of multilateral trade negotiations that are currently under way among members of the World Trade Organization (WTO).

The next section of the paper provides details of the recursive LINKAGE model and database. Section 3 presents results showing the effects of removing all current protection and subsidies as estimated by the LiNKAGE model. (In the Appendix the results are compared with those from a comparative static version similar to the GTAP model, to show how key model specifications can affect the results.) While global free trade is not expected in the foreseeable future, it provides a benchmark against which to consider partial reforms. Section 4 describes one ongoing reform effort, namely the WTO's multilateral Doha Development Agenda (DDA) negotiations. Results are 
presented in Section 5 for a number of possible DDA scenarios in which least developed countries may choose to participate. Some caveats are discussed in Section 6 before the final section summarizes the findings and draws out their policy implications for SSA.

\section{The global LINKAGE model and protection database}

The model used for this analysis is the World Bank’s global computable general equilibrium (CGE) model known as LiNKAGE (van der Mensbrugghe 2004). It is a relatively straightforward CGE model but with some characteristics that distinguish it from standard comparative static models such as the GTAP model (see Hertel 1997). A key difference is that it is recursive dynamic, so while it starts with 2001 as its base year it can be solved annually through to 2015. The dynamics are driven by exogenous population and labor supply growth, savings-driven capital accumulation, and labor-augmenting technological progress (as assumed for the World Bank's global economic prospects exercise, see World Bank 2004). In any given year, factor stocks are fixed. Producers minimize costs subject to constant returns to scale production technology, consumers maximize utility, and all markets - including for labor ${ }^{3}$ - are cleared with flexible prices. There are three types of production structures. Crop sectors reflect the substitution possibility between extensive and intensive farming. Livestock sectors reflect the substitution possibility between ranch versus range feeding. And all other sectors reflect the standard capital/labor substitution (with two types of labor: skilled and unskilled). There is a single representative household per modeled region, allocating income to consumption using the extended linear expenditure system. Trade is modeled using a

3 The results would be different if unemployment was present and changed as a consequence of the shocks considered, as discussed in Section 5 below. 
nested Armington structure in which aggregate import demand is the outcome of allocating domestic absorption between domestic goods and aggregate imports, and then aggregate import demand is allocated across source countries to determine bilateral trade flows.

There are six sources of protection in the model. The most important involves bilateral import tariffs. There are also bilateral export subsidies, plus domestic production subsidies in agriculture which may apply to intermediate goods, outputs, and payments to capital and land.

Three closure rules are used. First, government fiscal balances are fixed in any given year. ${ }^{4}$ The fiscal objective is met by changing the level of lump sum taxes on households. This implies that losses of tariff revenues are replaced by higher direct taxes on households. Second, the current account balance is fixed. Given that other external financial flows are fixed, this implies that ex ante changes to the trade balance are reflected in ex post changes to the real exchange rate. For example, if import tariffs are reduced, the propensity to import increases. Additional imports are financed by increasing export revenues, typically achieved by a real exchange rate depreciation. Finally, investment is driven by savings. With fixed public and foreign saving, investment will be affected by two factors: changes in the savings behavior of households, and changes in the unit cost of investment. The latter can play an important role in a dynamic model if imported capital goods are taxed. Because the capital account is exogenous, rates of return across countries can differ over time and across simulations. The model only solves for relative prices. The numéraire in the model, or

4 For the sake of simplicity they are fixed in US\$ terms at their base year level, minimizing potential sustainability problems; but this implies they decrease as a percentage of GDP for expanding economies. 
price anchor, is the export price index of manufactured exports from high-income countries. ${ }^{5}$ This price is fixed at unity in the base year and throughout the projection period to 2015.

The newest version of the LINKAGE model, Version 6.0, incorporates the latest release of the GTAP dataset, Release 6.0. ${ }^{6}$ Compared with Version 5 of the GTAP dataset, Version 6 has a 2001 base year instead of 1997, updated national and trade data and, importantly, a new source for the protection data. The new protection data come from a joint CEPII (Paris)/ITC (Geneva) project. The product of this effort, known as MAcMaps, is a tariff level detailed database on bilateral protection that integrates trade preferences, specific tariffs and a partial evaluation of non-tariff barriers, for example tariff rate quotas (TRQs). ${ }^{7}$ The new GTAP database has lower tariffs than the previous Version 5 database because of the inclusion of bilateral trade preferences and of major reforms between 1997 and 2001 such as continued implementation of the Uruguay Round Agreements and China's progress towards WTO accession (which contributed to the ratio of global exports plus imports-to-GDP rising from 44 to 46 percent over those four years).

The main source of trade distortion resides in tariffs or border barriers, although some countries - particularly high-income countries - also have significant agricultural production and export subsidies which are included in the database. The average import tariff for agriculture and

5 Throughout, the term 'high-income countries' refers to OECD countries (other than Mexico) plus the newly acceded members of the EU25, Hong Kong, Singapore and Taiwan. The term 'developing countries' refers to the rest of the world.

6 The Global Trade Analysis Project, otherwise known as GTAP, is an international consortium of trade researchers from universities, research institutions and national and international agencies. It is based at Purdue University. The GTAP Center provides four key resources to the trade community. First and foremost is an integrated and consistent international database for trade policy analysis. The current version is composed of 87 country/region groupings and 57 economic sectors. The second is a publicly available global trade model, known as the GTAP model. (N.B. The LINKAGE model is distinct from the GTAP model though it uses the same underlying database.) The third is an annual course in applied trade modeling. And finally, GTAP organizes and co-hosts the annual Conference on Global Economic Analysis. More information on the GTAP Center and project can be found at http://www.gtap.agecon.purdue.edu.

7 More information on the MAcMaps database is available in Bouët et al. (2004) and at http://www.cepii.fr/anglaisgraph/bdd/macmap.htm. 
food is 16 percent for high-income countries and 18 percent for developing countries, while for manufactures other than textiles and clothing it is 8 percent for developing countries and just 1.3 percent for high-income countries (Table 1). The averages, however, obscure large variations across countries, commodities and bilateral trades. For example, thanks to tariff preferences, exporters in Sub-Saharan Africa face slightly lower tariffs than do exporters elsewhere (compare columns 1 and 2 of Table 1). That table also shows that tariffs are very high in SSA, especially when South Africa is separated out.

The GTAP database provides country detail for just nine SSA countries. Besides South Africa (which accounted for 36 percent of Sub-Saharan African GDP in 2001), there are other eight but together they comprise only 14 percent of Sub-Saharan African GDP so we have aggregated then into a group referred to here as 'Other Southern Africa'. It comprises Botswana, Madagascar, Malawi, Mozambique, Tanzania, Zambia, Zimbabwe and (even though it is in central Africa) Uganda. Unfortunately the Rest of Sub-Saharan Africa, which accounts for half of the region's GDP, is not yet disaggregated in the GTAP model and so has to be examined as just one large subregion.

\section{Market and welfare impacts of current protection policies}

The LINKAGE model provides a baseline projection of the world economy first from 2001 to 2005 (following accession to WTO by China and Taiwan, EU expansion eastwards which added ten more countries to the EU15 in April 2004, and the end of textile and clothing quotas at the end of 
2004) and then to 2015 assuming no other policy changes. Deviations from that baseline in 2015, due to phased partial or total liberalization from 2005, are then examined.

Full liberalization of merchandise trade over the 2005-2010 period leads to global gains by 2015 of $\$ 287$ billion per year, according to the LINKAGE model. ${ }^{8}$ This provides an important benchmark against which to measure the benefits of future partial trade reforms. Another is the reforms incorporated in our pre-simulation experiment for the period from 2001 to 2004, due to the final-stage of the phase-out of the MFA, the accession of China and Taiwan to the WTO, and the eastern enlargement of the EU from 15 to 25 members. The impacts of those reforms on import tariffs are non-trivial: had those three reforms not been implemented, the dynamic gains in 2015 from freeing global merchandise trade would have been $\$ 350$ billion instead of $\$ 287$ billion, or an extra $\$ 63$ billion annually. Fully $\$ 33$ billion of that is due to the removal of MFA quotas and hence should be considered part of the Uruguay Round's legacy - assuming safeguards by high-income countries or export taxes by China do not replace textile and clothing quotas after the end-2004 phase-out.

Table 2 reports the distribution of the standard economic welfare or real income (equivalent variation) effects by 2015 of removing all merchandise (though not services) trade barriers and agricultural subsidies globally between 2005 and 2010. As already mentioned, removing those distortionary policies would generate $\$ 287$ billion in additional income in 2015, with two-thirds of that global gain accruing to the high-income countries. However, as a share of income, developing countries would do somewhat better, with an average increase of 0.8 percent compared to

8 This is very much larger than the $\$ 84$ billion generated by Hertel and Keeney (2005) using a new version of the GTAP model. Reasons for the difference are explained in the Appendix. 
0.6 percent for high-income countries. And Sub-Saharan Africa would do even better than the developing country average, enjoying a 1.1 percent income boost.

The numbers in parentheses in Table 2 show the amount of that welfare cost due to the effect on the international terms of trade for each country. For developing countries as a group the terms of trade effect is negative. It is positive for South Africa and Other Southern Africa, but negative for Rest of Sub-Saharan Africa. That is, as presumed by Panagariya (2004) and others, current trade distortions do improve the terms of trade for some developing countries, but evidently not for the countries of southern Africa. Notice also that the Rest of Sub-Saharan Africa would enjoy an even larger proportional increase than southern Africa in the volume of its trade if all barriers were removed globally (final column of Table 2).

To better understand the forces behind those welfare changes, it is helpful to look at the changing sectoral pattern of trade and to decomposes the terms of trade change for each of the three sub-regions of SSA into export and import price changes for all merchandise, and also for just food and agricultural products. In 2001 each of those three sub-regions was a very slight net exporter of food and agricultural products. Our base projection to 2015 shows little change for South Africa but the other two emerge as slightly greater net exporters of farm products assuming no further trade policy changes, and a little more so if there were to be full liberalization of merchandise trade globally over the next few years (Table 3). Since such a liberalization increases international prices for farm relative to non-farm products, that alone might lead one to be unsurprised that the three sub-regions are estimated to be net beneficiaries of a move to free trade, were it not for the complication of tariff preferences. 
A decomposition of the terms of trade is reported in Table 4. It reveals that the sub-regions' import prices rise for food and agricultural products and decline for other merchandise, as expected. This leads to a decline in the volume of farm imports such that the value of those imports hardly changes. But Table 4 also shows a decrease in farm and other merchandise export prices except for Other Southern Africa - a reflection in part of the erosion of preferences.

To assess the impacts of developing country liberalization versus high-income country liberalization in different economic sectors, the global welfare results are decomposed in Table 5. They suggest liberalization of agriculture and food markets yield 63 percent of the total global gains (similar to Hertel and Keeney's 66 percent). This is consistent with the high tariffs in agriculture versus other sectors, but is nonetheless remarkable given the low shares of agriculture in global GDP (4 percent) and global merchandise trade (9 percent). Nearly half (44 percent) of those gains are accounted for by the farm policies of high-income countries, but notice that as much of the gain to developing countries from farm reform is due to South-South agricultural liberalization as to increased access to high-income country markets (around $\$ 26$ billion). Almost the same is true for liberalizing trade in manufactures, which means reform by developing countries is as important in terms of economic welfare gains to the South as reform by high-income countries. The final column of Table 5 shows the welfare gains just for Sub-Saharan Africa. From those shares it is clear that agricultural reform in high-income countries is even more important to that region than to other developing countries, while textiles and clothing are relatively less important.

How would that full liberalization alter the real value of food and agricultural output and exports for SSA? Table 6 shows that real food and agricultural output and export values - even net of imports (see numbers in parentheses) -- would be substantially higher in SSA under global free 
trade. When disaggregated that remains true for the three sub-regions, except for the Rest of SSA's real value of food output which would be lower by 2015 than in the baseline, although only by 1 percent. Its food exports are higher even though food output is down because the higher price of importable food (see Table 4) has discouraged domestic sales there.

Of importance from a poverty viewpoint is real net farm incomes, and they would be greater for all three sub-regions, by between 8 and 16 percent (final column of Table 6). That suggests the effect on income of the rise in the price of importable farm and food products dominates the effect of the (smaller) fall in the price of exportables that was mentioned earlier (Table 4).

In volume terms, leaving aside processed food and looking just at agricultural output and employment on farms, that would grow faster in all three sub-regions of SSA over the next decade if all merchandise trade were freed (columns 1 and 2 of Table 7). So it is just in the processed food industry that output would be lower in Rest of SSA, not in farming.

If all merchandise were to be freed, then over the next decade the share of agriculture in the GDP of SSA would not decline, as it otherwise would have done, and the share of the sector's output that is exported would rise by much more than otherwise (Table 8).

Of particular interest to SSA cotton exporters is the impact of the removal of cotton subsidies (which raise producer prices by more than 50 percent in the US and even more in the EU) in this context of freeing all merchandise trade and agricultural subsidies. ${ }^{9}$ The model results suggest the price of cotton in international markets would be considerably higher in 2015, including for US exports because its subsidies would no longer depress that price. The price rise would not apply equally to all exporters however, because of product differentiation as captured in the

9 For more on the cotton subsidy issue, see Baffes (2005). The initiative to include cotton as an explicit item on the Doha Development Agenda, following demands by four West African cotton-exporting nations, is discussed in Sumner (2005). 
Armington elasticities. For Brazil and Australia, the rise is 8 percent, while for Sub-Saharan Africa it averages less than 2 percent (relative to the numéraire, which is the average price of exports of manufactures by high-income countries). However, cotton exports from Sub-Saharan Africa would be a huge 75 percent larger under this full reform scenario. The share of all developing countries in global exports would be 85 percent instead of 56 percent in 2015, vindicating the efforts by African cotton-exporting countries to ensure cotton receives specific attention in the Doha negotiations.

The relatively small percentage changes in net national economic welfare reported in Table 2 (less than 2 percent) hide the fact that redistributions of welfare among groups within each country following a trade reform can be much larger. This is clear from the impacts on real rewards to labor, capital and land that are reported in Table 9. The results strongly support the expectation from trade theory that real returns to farm land and unskilled labor would rise substantially in capital-scare SSA countries, and by more than wages of skilled workers, which in turn rise more than earnings of capitalists (Table 9). This means the number of jobs would grow faster for unskilled workers in the region. ${ }^{10}$ Given that more than two-thirds of SSA households are heavily dependent on agriculture for their livelihood, and that they and other unskilled laborers make up most of the people in poverty, this reform would improve equity and reduce poverty in all three subregions of SSA.

In summary, the above results for full merchandise trade liberalization suggest that, despite preference erosion, the SSA economy - and especially the poor within the region -- is harmed by current trade distortions. The next question to be addressed is: will the same be true of the smaller changes that would result from partial reforms of the sort being negotiated currently under the Doha

10 Had we specified some under-employment of unskilled workers instead of their full employment, this boost to their demand would have manifest itself in fewer unemployed and less as a wage rise - which possibly would reduce inequity and poverty even more. 
Development Agenda? That cannot be assumed, because the signs of the effects depend on, among other things, which sectors and which countries participate in the reform, how large the bound tariffs that are to be lowered are above applied rates, and the distribution of tariff preferences. To explore that issue further, attention now turns to the effects of some prospective Doha scenarios.

\section{The Doha negotiations}

To what extent are reform commitments likely to emerge from the Doha round? WTO trade negotiators focus on reductions not to the actual farm subsidies and the applied tariffs shown in Table 1 but rather to members' legally bound import tariffs, export subsidies and domestic support commitments. These are higher than applied rates in nearly all countries, but especially so in agriculture and particularly in poorer countries, as shown in Table 10. Hence if cuts to bound rates are sufficiently small, or the gap between bound and applied rates sufficiently large, no actual reform need take place from an agreed set of bound rate reductions.

The Doha round was launched in late 2001, but the following Trade Ministerial meeting, in Cancun in September 2003, ended with acrimony and without an agreement on how to proceed. At Cancun developing countries made it abundantly clear that further progress would not be possible without a commitment by high-income countries to significantly lower their import barriers and agricultural subsidies (including importantly for cotton). An intense period of consultations in July 2004 ended with a Decision on how the Doha Work Programme should proceed (WTO 2004). The so-called July Framework Agreement that emerged from that Decision reiterates the importance of keeping development at the heart of the Doha agenda and particularly stresses agricultural reform as 
key to that. In its Annexes, the Decision provides guidance as to how a Doha agreement might be structured, with frameworks for establishing modalities for agriculture and for non-agricultural market access, and for negotiations on trade facilitation, as well as providing recommendations for trade in services. We begin by summarizing what emerged with respect to the three agricultural pillars.

\section{Agricultural market access}

Jean, Laborde and Martin (2005) examine the consequences of different tariff-cutting formulae, bearing in mind the existing tariff rate quotas, the prevalence of tariff preferences for developing countries, the need to accommodate 'Sensitive' products, and the Special and Differential Treatment demanded by developing countries including provisions for 'Special' farm products. For this study, tariff cutting is implemented at the 6-digit HS commodity level and involves a detailed comparison of each country's bound tariffs, which are what negotiators focus on, with the applied tariffs on a given bilateral trade flow, which are what modelers need to deal with. The gap between bound and applied tariffs is the so-called binding overhang, and it can significantly blunt the impact of any negotiated outcome. Indeed in some scenarios, countries are not required to change their applied tariffs at all. Once the detailed tariff analysis was conducted, the results were aggregated up to the LINKAGE model's regions and sector levels by the CEPII staff in Paris (with special thanks to David Laborde). Note that the applied tariff cuts vary not only by sector, but also by trading partner - and may involve smaller or zero cuts on imports from those developing countries currently enjoying preferences. 
Jean et al. evaluate the consequences for 2001 applied rates of different approaches to liberalization, and particularly different degrees of top-down progressivity in the bound tariff cuts, as well as different degrees of Special and Differential Treatment in the extent of reform for developing as compared with developed countries. ${ }^{11}$ They look first at a proposal similar to the Harbinson progressive or tiered reduction formula (see WTO 2003b), but find that set of cuts would lead to very little import liberalization, because bound tariffs in many countries exceed applied rates by such large margins. As a result, Jean et al. focus on a set of reforms that involve cuts in applied agricultural protection rates that are at least 10 percentage points greater than in the Harbinson proposal. ${ }^{12}$ It yields an average cut in applied agricultural tariffs of about one-third globally in each of the scenarios we consider below.

\section{Agricultural domestic support}

Reductions in domestic support have been a particular concern of developing countries. This reflects the fact that the high-income countries are the major providers of such assistance, and many developing countries are concerned about the ability of their producers to compete with highincome country producers receiving large amounts of domestic support. While the marked asymmetry between high-income and developing countries is a concern, there is evidence, from Hertel and Keeney (2005) and from Hoekman, Ng and Olarreaga (2004), that the benefits to developing countries from reductions in domestic support are very minor compared with the

11 They assume that (as suggested in the Girard Text - see WTO 2003a) in the absence of a bound tariff on a good it is set at double the applied MFN rate.

12 They also explore a simple proportional cut formula that brings about the same reduction in average tariffs in highincome countries as a group, and developing countries as a group, as the tiered formulas used. Anderson, Martin and van der Mensbrugghe (2005a) compare those two and find almost as much welfare gain from the latter simpler approach. 
potential gains from reductions in market access barriers (which they estimate are responsible for all but one-tenth of the total potential benefits of freeing the world's agricultural markets).

The base from which reductions in domestic support will take place is the commitments on total bound Aggregate Measure of Support (AMS) agreed under Article 6 of the Uruguay Round Agreement on Agriculture. The July Framework proposes tiered reductions in the total bound AMS, with larger reductions by Members with higher initial AMS levels. In addition, it proposes capping product-specific AMS; and de minimis levels are to be reduced to an extent to be negotiated.

For modelling purposes we consider the implications of various degrees of cut in the Total Bound AMS on the actual distorting assistance that could be provided. A striking feature of the findings is that extraordinarily large reductions in bound AMS levels are required to bring about sizeable reductions in actual support -- an outcome required by paragraph 9 of the Framework. A tiered formula in which all countries with AMS notifications above 20 percent of the value of production cut their bound protection by 75 percent, and all others by 60 percent, bring about reductions in applied rates for only four WTO members: the US, the EU, Norway and Australia, as specified below.

\section{Agricultural export subsidies}

Farm export subsidies are inconsistent with GATT rules and for that reason alone deserve to be eliminated. The empirical analysis summarized in Hertel and Keeney (2005) shows that they are now only a small part of agricultural support programs: even when implicit subsidies in the form of food aid and export credits are included, they would be responsible for less than 5 percent of the total gain from freeing global farm trade. A gradual phasing out over the next decade of farm export 
subsidies is assumed in the scenarios considered below. Their elimination in isolation could harm a few food-importing and aid-dependent developing countries, but the poor in those countries can be assisted in far more efficient ways than via these measures.

\section{Non-agricultural market access (NAMA)}

Negotiations in the area of non-agricultural tariffs had barely begun by early 2005. There has been a clear indication that, with NAMA as with agricultural market access, developing countries can commit to lesser cust and longer phase-in periods and that least developed countries need not make any market-opening commitments. A Doha round is unlikely to involve nonagricultural bound tariffs being cut by more than 50 percent, so we assume that degree of cut by high-income countries and 33 percent by developing countries other than least developed ones (from whom no cuts are being demanded). However, since that bound cut may lead to very little reform by developing countries, given their high tariff bindings relative to their applied tariffs, a more ambitious scenario may see them prepared to commit to more reform in order to entice further cuts in high-income countries' agricultural and textiles tariffs. Perhaps the most optimistic possibility is that all developing (including least developed) countries agree to cut non-agricultural bound tariffs as much as high-income countries, that is, by 50 percent. Especially if that were coupled with similarly more-ambitious cuts in agricultural tariffs, high-income countries could well respond with larger commitments themselves not only in trade but also with development aid 
including as compensation to developing countries for losses arising from preference erosion and the removal of export subsidies. ${ }^{13}$

WTO members have been very slow in coming forward with proposals to reform services trade. It is conceivable that, as with the Uruguay Round, countries will make few meaningful commitments to open up their services sectors during the Doha round. For that reason, and because trade policies are less-adequately represented in trade models for services than for goods, we assume there will be no barrier reductions in this sector resulting from the Doha round - despite the fact that, as indicated in Hertel and Keeney (2005) and Winters et al. (2003), gains from services reform could well be enormous, including for developing countries.

\section{Possible Doha scenarios}

What will the Doha package ultimately contain? We assume there are no new trade facilitation measures, that agricultural export subsidies are eliminated, and that actual domestic support for agriculture is cut from 2001 levels in just four economies: by an average of 28 percent for the U.S., 18 percent for Norway, 16 percent for the EU and 10 percent for Australia. For agricultural market access we assume the tiered formula cut (described above) which brings down the average agricultural tariffs for developed countries as a group by 44 percent, and for developing countries as a group by 21 percent, with zero agricultural tariff cuts for least developed countries. Those reforms are first considered in isolation, as Scenario 1. We then add to Scenario 1 the cuts in non-agricultural tariff bindings of 50 percent in high-income countries, 33 percent in developing

13 The experience of earlier multilateral trade negotiations has shown that developing countries tended to receive greater market access only to the extent they are willing to give 'concessions', that is open up themselves, such is the reciprocal nature of these negotiations. See Finger $(1974,1976)$ for results from the Dillon and Kennedy rounds, respectively, and Finger and Schuknecht (2001) for Uruguay Round results. 
countries, and zero in least developed countries to obtain Scenario 2. Finally, Scenario 3 makes developing (including least developed) countries full participants in the round, undertaking the same reductions in bound (but not necessarily applied) tariffs as the high-income countries in Scenario 2.

The average tariffs resulting from all these scenarios are summarized in Table 11 for the three SSA sub-regions and for high-income and developing countries as group, along with the projected 2015 tariffs that would prevail without any further reform. What is clear is that, even in Scenario 3 in which all developing countries fully participate by cutting their bound tariffs as much as high-income countries, SSA would reduce their applied tariffs only a little.

\section{Estimated welfare, market and poverty effects of three Doha scenarios as of 2015}

The welfare consequences of implementing these various reforms over the 2005-2010 period and allowing the global economy to adjust to 2015 are summarized in Table 12 in both dollar terms and as percentage changes in real income in 2015. Column 1 suggests that agricultural liberalization using the tiered formula (Scenario 1) would generate a global gain of $\$ 75$ billion even without the inclusion of non-agricultural tariff reform. But almost all those benefits accrue to the reforming high-income countries (with whom we include farm-protective Korea and Taiwan even though their farm reforms are only two-thirds as large as for other high-income countries) such that developing countries excluding Korea and Taiwan would gain only $\$ 9$ billion because their bound tariffs are so high as to lead to almost no reform by them.

Three variants of Scenario 1 were explored to see how much the agricultural reform results for SSA vary with changes in assumptions. First, were high-income countries allowed to exclude from cuts even just 2 percent of their 'Sensitive’ farm products (and developing countries 4 percent 
of their 'Sensitive' and 'Special' farm products), those global gains would shrink from \$75 billion to just \$18 billion, and SSA economies as a group would be no better instead of slightly better off. Second, were high-income countries not to reduce domestic support to their farmers, SSA's welfare gain would shrink from 0.10 to 0.05 percent. And third, were high-income countries not to reduce farm export subsidies, SSA's welfare gain would increase from 0.10 to 0.23 percent (see details in Anderson, Martin and van der Mensbrugghe 2005a).

Scenarios 2 and 3 add non-agricultural tariff cuts to the agricultural reforms in the preceding scenarios. In Scenario 2, where Special and Differential Treatment is provided for developing countries' non-agricultural cuts (as is the case for agricultural cuts), the gain nearly doubles for SSA countries as a group by adding these non-farm reforms, relative to Scenario 1 where only agriculture is cut. In Scenario 3, the developing and least developed countries fully engage in the Doha reform process, foregoing the opportunity to make lesser cuts as provided for in Scenarios 1 and 2. That boosts SSA welfare considerably more, although even then their bound tariff cuts do not lead to much in the way of cuts to applied tariffs (see Table 11). Within SSA, the gains vary with the depth of actual tariff cuts: South Africa gains most, then Other Southern African countries, then the Rest of SSA so long as it participates more fully in reform (otherwise it loses very slightly).

The real income gain to SSA in Scenario 3 in percentage terms is almost the same as for developing countries as a whole, namely 0.27 percent. This is so -- despite SSA cutting its applied tariffs less than other developing countries - because SSA economies are more distorted at the outset (Table 11). SSA gains almost certainly could be greater if the region was to choose unilaterally to liberalize more so as to get greater efficiency gains to offset the terms of trade losses 
suffered either as net food importers or as recipients of tariff preferences that have eroded with the decline in high-income countries’ MFN tariffs.

How big would be the consequences of reform for SSA agriculture over the implementation period post-2004? Table 7 shows what that annual farm output and employment growth to 2015 would be in the baseline (no policy changes post-2004), what it would be if all distortions to merchandise trade were removed globally, and what it would be under Doha Scenario 2. Table 8 provides similar comparisons for food and agriculture's share of GDP, and the proportion of the sector's output that is exported. Clearly that Doha scenario would take SSA agriculture and farm households some distance towards where they would be under global free trade in all merchandise. ${ }^{14}$ As with full reform, the relatively small percentage changes in net national economic welfare from partial reform hide the fact that redistributions of welfare among groups within each country can be much larger. In particular, real returns to farm land and unskilled labor would rise by more than rewards to other factors, hinting that at least these Doha scenarios (involving significant cuts in agricultural protection) would improve equity and reduce poverty in SSA as a region. ${ }^{15}$

The consequences of Scenario 2 for SSA trade patterns are summarized in Table 13. They show the region's overall export increase of $\$ 1.2$ billion per year by 2015 would comprise an increase of $\$ 2.6$ billion in agricultural and processed food exports and a decrease of $\$ 1.4$ billion in other merchandise exports. Only half of that increase in farm products would go to high-income

14 That is less the case for employment than for output. This finding of only small intersectoral labor movements in response to partial trade reform is consistent with econometric evidence of adjustments to past trade reforms (see, e.g., Wacziarg and Wallack 2004).

15 To determine the poverty impacts in individual countries there is no substitute for detailed national analysis using models with various types of households explicitly represented. That is the purpose of the forthcoming volume by Hertel and Winters (2005), in which separate chapters are devoted to three SSA countries (Cameroon, Mozambique and Zambia). 
countries; the rest is split one-third to other SSA countries and two-thirds to developing countries in other regions. Exports of other merchandise to non-SSA developing countries also expand, so that overall this Doha scenario would see SSA exports being redirected from high-income to developing countries -- but with no net increase in trade within SSA because of its modest reforms in this scenario. On the import side, there is a slight increase in food imports but only from developing countries, while the opposite is true for other merchandise imports as all countries specialize more in what they do best. Notice from the final two columns of Table 13 that this scenario boosts SSA trade by only a small fraction of what would happen with full global liberalization.

The impact of reform on the various product markets within Sub-Saharan Africa is summarized in Table 14. Doha Scenario 2 would change domestic consumption of most products by only a small fraction of 1 percent. Production and exports would change somewhat more, with cotton, sugar, meat and (from a small base) dairy products being the main expanding industries. Self sufficiency (production as a percentage of domestic consumption) would rise for virtually all agricultural and food products, but the rise is small. Under full liberalization, by contrast, SSA would specialize somewhat more within the agricultural sector, causing some self-sufficiency ratios to be higher and others lower.

Finally, consider the critical issue of poverty. Assessing reform impacts on poverty with a global model could be seen as somewhat heroic. Yet despite the aggregate nature of the model, it nonetheless contains quite a bit of information from which it is possible to make some judgment about the possible changes in poverty. The simplest approach is to take the growth in real income, apply an estimated income-to-poverty elasticity, and assess the impacts on the headcount index. This approach assumes distributional neutrality, that is, that the poor receive the same increase in 
real income as the average household in the economy. ${ }^{16}$ A somewhat more detailed approach is to link key model variables to the possible change in the average per capita consumption of the poor, that is, to capture from model results some distributional aspects of the changes in real income and not simply the average gain. We have done this by calculating the change in the real wage of unskilled workers, deflating it by a food/clothing consumer price index which is presumably more relevant for the poor than the total price index. While these simple calculations are not a substitute for more-detailed individual country case study analysis using detailed household surveys as in, for example, Hertel and Winters (2005), they are able to give a broad region-wide indication.

Table 15 summarizes the key results from the global full liberalization scenario and some of the three Doha alternatives. Under the full merchandise trade liberalization scenario, extreme poverty in developing countries would drop by 32 million in 2015 relative to the baseline level of 622 million, a reduction of 5 percent. The majority of the poor by 2015 are projected to be in SSA, and there the reduction would be 6 percent. With real incomes climbing by only 0.9 percent, this would seem to imply a relatively high poverty to income elasticity. However, recall that in our calculations, we base our poverty calculations on the change in the real wage of unskilled workers deflated by the food and clothing consumer price index. The average change in the real unskilled wage over all developing countries is 3.6 percent, or four times greater than the average income increase. Critically, we are assuming that the change in unskilled wages is fully passed through to households. Also, while the model closure has the loss in tariff revenues replaced by a change in

16 The World Bank's headcount index forecast is derived from an estimated Lorenz curve based on the most recently available household survey and not from an elasticity approach. A forecast of the growth of per capita consumption is plugged into the Lorenz curve based functional form for the headcount index-assuming distribution neutrality. See Datt (1998) for a derivation of this methodology. 
direct household taxation, the poverty calculation assumes that these increases only affect skilled workers and high-income households—a realistic assumption in many developing countries. ${ }^{17}$

Under the Doha scenarios reported in Table 15, the poverty impacts are far more modest. The number of poor living on \$1/day or less would fall by 2.5 million in the case of the core Doha Scenario 2 (of which 0.5 million are in SSA) and by 6.3 million in the case of Doha Scenario 3 (of which 2.2 million are in SSA). This corresponds to the relatively modest ambitions of the merchandise trade reforms as captured in these Doha scenarios. If only agriculture was reformed (Doha Scenario 1) there would be much less poverty alleviation globally and none at all in SSA. This shows the importance for poverty of including manufactured products in the Doha negotiations.

\section{Caveats}

Results such as those presented above are always dependent on the assumptions, data and parameters underlying them and so are subject to numerous qualifications. One that is particularly important to highlight has to do with the way preferences are treated in the Version 6 GTAP database. In previous versions of that database, only key reciprocal preferences were included, whereas the new Version 6 added non-reciprocal tariff preferences provided by high-income countries for their imports from developing countries under numerous arrangements such as the Generalized System of Preferences (GSP), the EU's provisions for former colonies under the Africa, Caribbean and Pacific (ACP) program and more recently for least developed countries under

17 Even if the fiscal closure affects a domestic sales or value added tax instead of direct taxes on households, in many countries food, at least, is typically exempt from taxation, or the tax is difficult in practice to collect because of the informal nature of many food markets. 
the Everything But Arms (EBA) agreement, and likewise the US’s Africa Growth and Opportunity Act (AGOA) and Caribbean Basin Initiative (CBI). In preparing this new database, CEPII made the assumption that there are no rules of origin (ROOs) or the like which discourage developing countries from taking full advantage of those preferences (even though we know ROOs often lead to underutilization); and we assume perfect competition between traders in the two sets of countries, which determines how rents from those preferences are shared between the exporting and importing countries (even though we know the high-income country importers often have more market power than the developing country exporters of standard commodities such that the latter receives a smaller share of the rents than our analysis generates). ${ }^{18}$ We therefore overstate the extent of preference erosion that would occur for especially least developed countries, and so understate the gains to SSA from trade reform. If instead those non-reciprocal preferences were excluded from the database, we would overestimate SSA gains from high-income country trade reform. ${ }^{19}$ The difference is not expected to be great though: CEPII staff ran a scenario similar to our Doha Scenario 1, using their global Mirage model, and got very similar real income results for SSA with preferences included and only slightly higher gains (0.2 instead of 0.1 percent) when non-reciprocal preferences were excluded from the protection database (Bouet, Fontagne and Jean 2005, Table 6.9).

18 Evidence that the preference margin is often eroded by complex rules of origin, and that the rent is shared between importing and exporting countries with the latter getting less the more trade is concentrated on standard commodities, can be found in Olarreaga and Ozden (2004) and Ozden and Sharma (2004). A recent partial equilibrium study found that in practice export revenue losses from preference erosion are likely to be limited to a small subset of countries, primarily small island economies dependent on exports of sugar, bananas and, to a far lesser extent, textiles (Alexandraki and Lankes 2004).

19 A further complication is that the ACP non-reciprocal preference scheme is to be replaced from 2008 with reciprocal Economic Partnership Agreements (EPAs) between those countries and the EU. 
Another important caveat worth stressing is that the above results do not incorporate the fact that trade reform typically boosts factor productivity. ${ }^{20}$ If instead we were to assume productivity is positively related to changes in sectoral openness (exports as a share of output), as specified in World Bank (2002), then the estimated global gains from freeing merchandise trade increase by 38 percent. More importantly, they increase by 44 percent for middle-income countries and by 155 percent for low-income countries, because the initial protection rates are so much higher there. For this reason much more than because of our treatment of preferences, the welfare effects presented in this paper should be taken as very much lower-bound estimates. This is especially so if high-income countries were to compensate least developed countries for preference erosion and that assistance were to be directed toward trade facilitation investments such as transport infrastructure (see below).

The above analysis does not include costs of adjustment to reform, but these are typically far less than commonly assumed. ${ }^{21}$ Indeed, the structural changes that take place over time in the normal course of economic growth are shown above to be typically very much larger than the small additional changes that would accompany gradual and partial trade liberalization. Furthermore, adjustment assistance schemes (financed by foreign aid in the case of low-income countries) are a way to help fund adjustment to trade reform - and they are just one-off payments, whereas the costs of not reforming continue into the future.

\section{Summary and policy implications}

20 See footnote 2 above.

21 For a review of the empirical literature supporting this view for a range of countries, see Anderson (2004, pp. 56062). As mentioned earlier, adjustment would be even easier if there were some unskilled workers underemployed in rural areas since they would be in greater demand as farm output nd employment rises slightly. 
Several findings in the above results are worth reiterating. First is that moving to free global merchandise trade not only would boost real incomes in developing countries, and especially in Sub-Saharan Africa, but it would do so proportionately more than in high-income countries. This is true even for SSA other than southern Africa, whose economies would suffer a terms of trade loss in part because of a loss due to preference erosion (and despite us overstating the degree of tariff preference currently enjoyed by these countries).

Second, agricultural reform is crucial for reaping those gains: it accounts for nearly twothirds of the potential benefits both for developing and developed countries.

Third, reform by developing countries themselves is as important for their gains, and in agriculture as much as in manufactures, as is reform by high-income countries.

Fourth, farm employment, the real value of agricultural output and exports, the real returns to farm land and unskilled labor, and real net farm incomes would all rise substantially in capitalscarce SSA countries with a move to free merchandise trade. Given that more than two-thirds of SSA households are heavily dependent either directly or indirectly on agriculture for their livelihood, and that they and other unskilled laborers make up most of the people in poverty, there is a good chance that such a reform would improve equity and reduce poverty in all three sub-regions of SSA. And this is indeed what shows up in terms of the change in poverty headcount for the region using the simple income-to-poverty elasticity approach.

And fifth, a Doha partial liberalization of merchandise trade could take SSA some way towards those desirable outcomes, but more so the more the region itself reduces its tariff binding overhang and cuts actual applied tariffs, and provided non-agricultural liberalization is included. In 
the scenarios considered above, SSA gains proportionately as much as other developing countries in economic welfare terms. This is despite cutting its applied tariffs less, and is because its own trade distortions are larger than those of other developing countries.

SSA gains could be greater if the region chose unilaterally to liberalize more, so as to get greater efficiency gains to offset the terms of trade losses suffered either as net food importers or as recipients of tariff preferences that have eroded with the decline in high-income countries' MFN tariffs.

Clearly, agricultural reforms need to be significant if the Doha agreement is to be prodevelopment and pro-poor. Outlawing agricultural export subsidies is the obvious first step. That will bring agriculture into line with the basic GATT rule against such measures, and in the process help to limit the extent to which governments encourage agricultural production by other means (since it would raise the cost of surplus disposal). Concurrently, domestic support bindings must be cut hugely to reduce binding overhang. In so doing, the highest-subsidizing countries, namely the EU, US and Norway, need to reduce their support not just for the sake of their own economies, but also to encourage SSA and other developing countries to reciprocate by opening their markets as a quid pro quo. Even more importantly, agricultural tariff bindings must be cut substantially before some genuine market opening can occur. Exempting even just a few 'Sensitive' and 'Special' products could reduce hugely the gains from reform, since they are likely to be the tariff peak items (although if their binding tariff rate quotas expand more so as a consequence, this could limit the diminution at least for those exporters lucky enough to have in-quota access). Expanding nonagricultural market access at the same time as reforming agriculture is equally important for SSA. In any case, a balanced exchange of concession is impossible without adding other sectors, and it 
needs to be more than just textiles and clothing (which also benefit developing countries disproportionately) even though they are the other highly distorted sector.

South-South "concessions" also are needed for developing countries to get the most out of the Doha round. This means developing countries should reconsider the provisions in the July 2004 framework agreement allowing them lesser cuts and a slower phase-in of reforms. Since developing countries are trading so much more with each other now, they are the major beneficiaries of reforms by other developing countries. Even SSA's least developed countries should consider reducing their tariff binding overhang, since doing that in the context of Doha gives them more scope to demand "concessions" from richer countries than if they hang on to that aspect of Special and Differential Treatment. $^{22}$

In conclusion, and in answer to the question posed in the paper's title, it appears SSA economies could indeed gain from full multilateral trade reform. Of the partial liberalizations considered above, South Africa and even more so other countries in southern Africa would gain, while the Rest of SSA is estimated to lose slightly because few countries in that sub-region cut their applied tariffs in those Doha scenarios (even when they fully participate, such is the extent of their binding overhang). However, the poorest people in SSA, namely farmers and unskilled laborers, appear likely to gain most from global trade liberalization. To realize more of their potential gains from trade, SSA countries would need to forego some of the Special and Differential Treatment they have previously demanded in terms of making lesser tariff cuts, and perhaps also commit to additional unilateral trade (and complementary domestic) reforms, and to invest more in trade facilitation. High-income countries could encourage them to do so by being willing to open up their

While no extra market access results immediately from just reducing (as distinct from eliminating) binding overhang, it is nonetheless capable of doing so in the longer term as market conditions change (Francois and Martin 2004), and hence is valued by trading partners as a step towards market liberalization. 
own markets more to developing country exports in response to greater opening by developing countries, and by providing more targeted aid. ${ }^{23}$

To that end, new proposals have been put forward to reward developing country commitments to greater trade reform with an expansion of trade-facilitating aid, to be provided by a major expansion of the current Integrated Framework, which is operated by a consortium of international agencies for least developed countries (Hoekman 2004, 2005). This may well provide an attractive path for developing countries seeking to trade their way out of poverty through expanding exports to take advantage of new market openings. Making the aid flow commensurate with the degree to which a developing country is willing to commit to opening its own market is not only consistent with current practices of international financial institution to focus assistance in countries willing to reform. As well, it would help offset the tendency for an expanded aid flow to cause a real exchange rate appreciation that could otherwise thwart efforts to expand exports (see Commission for Africa 2005, pp. 296-97). Moreover, this is potentially a far more efficient way for developed countries to assist people in low-income countries than the current systems of tariff preferences.

${ }^{23}$ In that process, high-income countries would be rewarded economically: Table 5 shows high-income countries have nearly as much to gain from developing country trade reform as from reform within their own country group. 


\section{References}

Alexandraki, K. and H.P. Lankes (2004), 'The Impact of Preference Erosion on Middle-Income Countries’, IMF Working Paper No. 04/169, International Monetary Fund, Washington DC, September.

Anderson, K. (2004), 'Subsidies and Trade Barriers’, Ch. 10 in Global Crises, Global Solutions, edited by B. Lomborg, Cambridge and New York: Cambridge University Press.

Anderson, K. and L.A. Jackson (2005), 'Some Implications of GM Food Technology Policies for Sub-Saharan Africa', Journal of African Economies 14(3), September (forthcoming).

Anderson, K., W. Martin and D. van der Mensbrugghe (2005a), 'Market and Welfare Impacts of Doha Reform Scenarios', Ch. 12 in Agricultural Trade Reform and the Doha Development Agenda, edited by W. Martin and K. Anderson, Washington DC: World Bank (forthcoming).

Anderson, K., W. Martin and D. van der Mensbrugghe (2005b), 'Global Impacts of the Doha Scenarios on Poverty', Ch. 18 on Putting Development Back Into the Doha Agenda: Poverty Impacts of a WTO Agreement, edited by T.W. Hertel and L.A. Winters, Washington DC: World Bank (forthcoming).

Baffes, J. (2005), 'The “Cotton Problem”, World Bank Research Observer 20(1): 109-43, Spring.

Bouët, A., Y. Decreux, L. Fontagné, S. Jean and D. Laborde (2004), 'A Consistent, ad valorem Equivalent Measure of Applied Protection Across the World: The MAcMap-HS6 Database’, mimeo, CEPII, Paris, 20 December. 
Bouët, A., L. Fontagné and S. Jean (2005), 'Is Erosion of Preferences a Serious Concern?’, Ch. 6 in Agricultural Trade Reform and the Doha Development Agenda, edited by W. Martin and K. Anderson, Washington DC: World Bank (forthcoming).

Chen, S. and M. Ravallion (2004), 'How Have the World’s Poorest Fared Since the Early 1980s?' World Bank Economic Review 19(2): 141-70.

Commission for Africa (2005), Our Common Interest, London: UK Department for International Development, March.

Datt, G. (1998), ‘Computational Tools for Poverty Measurement and Analysis’, FCND Discussion Paper No. 50, Food Consumption and Nutrition Division, International Food Policy Research Institute, October, Washington DC.

Dollar, D. and A. Kraay (2004), 'Trade, Growth and Poverty', Economic Journal 114: F22-F49, February.

DTI (2004), 'Liberalization and Globalization: Maximizing the Benefits of International Trade and Investment’, DTI Economics Paper No. 10, UK Department of Trade and Industry, London, July.

Finger, J.M. (1974), 'GATT Tariff Concessions and the Exports of Developing Countries: United States Concessions at the Dillon Round', Economic Journal 84(335): 566-75, September.

Finger, J.M. (1976), 'Effects of Kennedy Round Tariff Concessions on the Exports of Developing Countries’, Economic Journal 86(341): 87-95, March.

Finger, J.M. and L. Schuknecht (2001), 'Market Access Advances and Retreats: The Uruguay Round and Beyond', Ch. 15 in Developing Countries and the WTO: A Pro-Active Agenda, edited by B. Hoekman and W. Martin, Oxford: Blackwell Publishers. 
Francois, J.F. and W. Martin (2004), ‘Commercial Policy, Bindings and Market Access’, European Economic Review 48(3): 665-79, June.

Hertel, T.W. (ed.) (1997), Global Trade Analysis: Modeling and Applications, Cambridge and New York: Cambridge University Press.

Hertel, T.W. and R. Keeney (2005), 'What’s at Stake: The Relative Importance of Import Barriers, Export Subsidies and Domestic Support', Ch. 2 in Agricultural Trade Reform and the Doha Development Agenda, edited by W. Martin and K. Anderson, Washington DC: World Bank (forthcoming).

Hertel, T.W. and L.A. Winters (eds.) (2005), Putting Development Back Into the Doha Agenda: Poverty Impacts of a WTO Agreement, Washington DC: World Bank (forthcoming).

Hoekman, B. (2004), 'Operationalizing the Concept of Policy Space in the WTO: Beyond Special and Differential Treatment', paper presented to the $3^{\text {rd }}$ Annual Conference on Preparing the Doha Development Round, European University Institute, 2-3 July.

Hoekman, B. (2005), 'Making the WTO More Supportive of Development', Finance and Development pp. 14-18, March.

Hoekman, B., F. Ng and M. Olarreaga (2004), 'Agricultural Tariffs versus Subsidies: What’s More Important for Developing Countries?’ World Bank Economic Review 18(2): 175-204.

Jean, S., D. Laborde and W. Martin (2005), 'Consequences of Alternative Formulas for Agricultural Tariff Cuts', Ch 4 in Agricultural Trade Reform and the Doha Development Agenda, edited by W. Martin and K. Anderson, Washington DC: World Bank (forthcoming). 
Olarreaga, M. and C. Ozden (2004), 'AGOA and Apparel: Who Captures the Tariff Rent in the Presence of Preferential Market Access?', The World Economy 27 (forthcoming).

Ozden, C. and G. Sharma (2004), 'Price Effects of Preferential Market Access: The CBI and the Apparel Sector', Policy Research Working Paper 3244, World Bank, Washington DC, March.

Panagariya, A. (2004), 'Subsidies and Trade Barriers: Alternative Perspective 10.2', pp.592-601 in Global Crises, Global Solutions, edited by B. Lomborg, Cambridge and New York: Cambridge University Press.

Rodrigeuz, F. and D. Rodrik (2001), 'Trade Policy and Economic Growth: A Skeptic’s Guide to Cross-National Evidence', in B.S. Bernanke and K. Rogoff (eds.), NBER Macroeconomics Annual 2000, Cambridge MA: MIT Press.

Sumner, D.A. (2005), 'Reducing Cotton Subsidies: The DDA Cotton Initiative', Ch. 10 in Agricultural Trade Reform and the Doha Development Agenda, edited by W. Martin and K. Anderson, Washington DC: World Bank (forthcoming).

van der Mensbrugghe, D. (2004), “LinKAGE Technical Reference Document: Version 6.0,” mimeo, The World Bank, Washington, DC. Accessible at http://siteresources.worldbank.org/INTPROSPECTS/Resources/3349341100792545130/LinkageTechNote.pdf

Wacziarg, R. and J.S. Wallack (2004), 'Trade Liberalization and Intersectoral Labor Movements', Journal of International Economics 64(2): 411-39, December.

Wacziarg, R. and K.H. Welch (2003), ‘Trade Liberalization and Growth: New Evidence’, NBER Working Paper 10152, Cambridge MA, December. 
Winters, L.A. (2002), 'Trade Liberalisation and Poverty: What Are the Links?' The World Economy 25(9): 1339-68, September.

Winters, L.A. (2004), ‘Trade Liberalization and Economic Performance: An Overview’, Economic Journal 114: F4-F21, February.

Winters, L.A., N. McCulloch and A., McKay (2004), 'Trade Liberalization and Poverty: The Empirical Evidence’, Journal of Economic Literature 62(1): 72-115, March.

Winters, L.A., T. Walmsley, Z.K. Wang and R. Grynberg (2003), 'Liberalizing Temporary Movement of Natural Persons: An Agenda for the Development Round', The World Economy 26(8): 1137-61, August.

World Bank (2002), Global Economic Prospects and the Developing Countries 2002: Making Trade Work for the Poor, Washington D.C.: The World Bank.

World Bank (2004), Global Economic Prospects: Realizing the Development Promise of the Doha Agenda, Washington DC: The World Bank.

WTO (2003a), 'Negotiating Group on Market Access: Report by the Chairman', TN/MA/12, Geneva: World Trade Organization, 1 September (The Girard Text).

WTO (2003b), 'Negotiations on Agriculture: First Draft of Modalities for the Further Commitments', TN/AG/W/1/Rev.1, Geneva: World Trade Organization, 19 March (The Harbinson Draft).

WTO (2004), 'Decision Adopted by the General Council on 1 August 2004', WT/L/579, Geneva: World Trade Organization, 2 August (The July Framework Agreement). 


\section{Appendix: Comparison of LINKAGE model results with those from the GTAP-AGR model}

Using the same GTAP Version 6.0 2001 database, our analysis using the LINKAGE model provides considerably larger welfare gains from full trade liberalization than generated by Hertel and Keeney (2005) using a variant on the standard GTAP model called GTAP-AGR. To understand the reasons behind this difference, we altered the LINKAGE model so that it mimics the comparative static GTAP-AGR model as of 2001, and then we also altered assumptions about elasticities and factor mobility to make them similar to those used by Hertel and Keeney.

Obtaining a comparative static version of the LINKAGE model involves only a few modifications to the recursive dynamic version. Specifically, the 'new' elasticities of substitution in production are imposed to mimic the long-term properties of the dynamic model, capital is assumed to be perfectly mobile, and adjustment costs are ignored. But the big difference between the comparative static and dynamic version results is the change in the structure of the global economy by 2015, due to growth in factor stocks and changes in the relative weights of countries and sectors in the global economy over those 14 years.

Table A reports what the LINKAGE model says is the welfare cost of global trade barriers and agricultural subsidies in 2001 under differing assumptions, as compared with their cost in 2015. First, by scaling the 2015 dynamic results back to 2001 by assuming the percentage effect on income in each region is the same in 2001 as in 2015 reduces the real global cost from \$278 billion to $\$ 150$ billion - simply because each regional economy is smaller. Second, when the dynamic effects themselves are removed, the global comparative static cost shrinks to $\$ 121$ billion. Third, if 
the long-run Armington elasticities ${ }^{24}$ used in the LINKAGE model (which we believe are more appropriate for the long-run analysis being undertaken in the current study) are replaced be the medium-term ones used in Hertel and Keeney’s GTAP-AGR model, ${ }^{25}$ the real global cost shrinks further to $\$ 82$ billion. In short, those three differences between the two models almost fully explain the different aggregate results, since that $\$ 82$ billion is very close to Hertel and Keeney’s $\$ 84$ billion comparative static estimate of the gains from freeing merchandise trade globally. One other difference between the LINKAGE and GTAP models has to do with agricultural land: GTAP assumes a fixed supply of farm land and limited land mobility between farm sectors whereas the LINKAGE model assumes farm land supply in the long run is somewhat responsive to farm product prices and that there is complete mobility of that land among farming enterprises in the long run. ${ }^{26}$ The final column of Table A shows that replacing those two assumptions with the ones adopted in the GTAPAGR model does almost nothing to the global cost of trade-distorting policies, although the distribution of those costs is somewhat different.

24 These elasticities represent the top-level Armington elasticity, i.e. between domestic demand and aggregate import demand. The second-level Armington elasticity, i.e. across trading partners, is set at twice the top-level elasticity.

25 The new GTAP elasticities are the outcome of significant econometric work and are higher than the standard Armington elasticities used in previous releases of GTAP. While recognizing the extensive work behind the new elasticities, the controversy underlying these key parameters continues. The new GTAP elasticities reflect a move towards mid-range Armington elasticities, but are still much lower than those used by some, notably Tarr and Rutherford and their associates. The LINKAGE model elasticities are above those in GTAP-AGR but still in the midrange, and are the outcome of literature surveys, best guesses and adjustments that have been undertaken over a 15year period since the inception of the LINKAGE model and its predecessors. The difference between these elasticities for each good is detailed in Anderson, Martin and van der Mensbrugghe (2005a, Appendix Table A12.4).

26 In the standard LINKAGE model, an upward-sloping supply function is implemented for land, with supply elasticities higher for land-abundant countries than for land-scarce countries. There is also perfect land mobility across farm enterprises. In the final simulation the supply elasticity is set to 0 and the land transformation elasticity is set to 1 . 
Table 1: Average applied import tariffs, by sector and region, 2001

(percent, ad valorem equivalent)

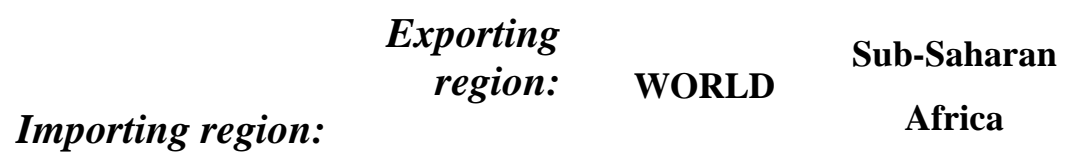

Agriculture and food

$\begin{array}{lrr}\text { High-income countries }^{\mathrm{b}} & 16 & 11 \\ \text { Developing countries }^{\mathrm{a}} & 18 & 13 \\ \text { South Africa }_{\text {Other Southern }}^{\mathrm{c}} \text { Africa } & 9 & 2 \\ \text { Rest of Sub-Saharan Africa } & 12 & 11 \\ & 21 & 15\end{array}$

\section{Textiles and wearing apparel}

High-income countries $^{\mathrm{b}}$

Developing countries $^{\mathrm{a}} \quad 17 \quad 10$

$\begin{array}{lll}\text { South Africa } & 22 & 9\end{array}$

Other Southern ${ }^{\mathrm{c}}$ Africa $\quad 13 \quad 6$

Rest of Sub-Saharan Africa $\quad 26 \quad 8$

\section{Other manufactures}

High-income countries ${ }^{b}$

Developing countries ${ }^{\mathrm{a}}$

$\begin{array}{rr}1.3 & 0.4 \\ 8 & 7 \\ 5 & 0.2 \\ 8 & 6 \\ 14 & 6\end{array}$

\section{All merchandise}

High-income countries $^{\mathrm{b}} \quad 3 \quad 3$

Developing countries $^{\mathrm{a}} \quad 10 \quad \mathbf{8}$

$\begin{array}{lll}\text { South Africa } & 7 & \mathbf{1}\end{array}$

Other Southern ${ }^{\mathrm{C}}$ Africa $\quad 9 \quad 7$

Rest of Sub-Saharan Africa $\quad 16 \quad 9$

${ }^{\mathrm{a}}$ These import-weighted averages incorporate tariff preferences provided to developing countries, unlike earlier versions of the GTAP database.

${ }^{\mathrm{b}}$ High-income countries include the newly industrialized East Asian customs territories of Hong Kong, Korea, Singapore and Taiwan as well as the European transition economies that joined the EU in April 2004.

c Botswana, Madagascar, Malawi, Mozambique, Tanzania, Uganda, Zambia, Zimbabwe. These countries accounted for 14 percent of Sub-Saharan African GDP in 2001 (while South Africa accounted for 36 percent and the Rest of Sub-Saharan Africa accounted for 50 percent.

Source: Anderson, Martin and van der Mensbrugghe (2005a, Tables A12.3) 
Table 2: Impacts on real income and on the volume and terms of trade from full liberalization of global merchandise trade, 2015

\begin{tabular}{|c|c|c|c|c|}
\hline & $\begin{array}{c}\text { Real } \\
\text { income }^{\mathrm{a}}\end{array}$ & $\begin{array}{c}\text { Real } \\
\text { income } \\
\text { (\% } \\
\text { change) }\end{array}$ & $\begin{array}{c}\text { Terms of } \\
\text { trade } \\
(\% \\
\text { change) } \\
\end{array}$ & $\begin{array}{c}\text { Volume } \\
\text { of trade } \\
\text { (\% } \\
\text { change) }\end{array}$ \\
\hline High-income countries & $202(30)$ & 0.6 & 0.6 & 5 \\
\hline Developing countries & $86(-29)$ & 0.8 & -0.6 & 20 \\
\hline Sub-Saharan Africa & $4.8(-1.8)$ & 1.1 & -0.7 & 23 \\
\hline South Africa & $1.3(0.0)$ & 0.9 & 0.4 & 16 \\
\hline Other Southern Africa & $1.0(0.5)$ & 1.5 & 2.7 & 17 \\
\hline Rest of Sub-Saharan Africa & $2.5(-2.3)$ & 1.1 & -1.9 & 27 \\
\hline World total & 287 & 0.7 & 0.0 & 9 \\
\hline \multicolumn{5}{|c|}{ a Numbers in parentheses show the amount due to changes in the terms of trade } \\
\hline \multicolumn{5}{|c|}{ Source: Authors' World Bank LINKAGE model simulations. } \\
\hline
\end{tabular}


Table 3: Value of exports net of imports of agricultural and processed food products, actual 2001 and projected 2015

$\begin{array}{lcrr} & \begin{array}{r}\text { (\$ billion) } \\ \mathbf{2 0 1 5}\end{array} & \begin{array}{r}\mathbf{2 0 1 5} \text { full trade } \\ \text { liberalization }\end{array} \\ \text { Sub-Saharan Africa } & \mathbf{2 0 0 1} & 19 & 27 \\ \text { South Africa } & 6 & 1 & 3 \\ \text { Other Southern Africa } & 2 & 6 & 10 \\ \text { Rest of Sub-Saharan Africa } & 2 & 11 & 14\end{array}$

Source: Authors’ World Bank LINKAGE model simulations 
Table 4: Impact of full liberalization of global merchandise trade on indexes of real ${ }^{\mathrm{a}}$ export and import prices

\begin{tabular}{lrrrrrr}
\multicolumn{3}{c}{ (percent) } \\
& \multicolumn{3}{c}{ Export prices } & \multicolumn{3}{c}{ Import prices } \\
\cline { 2 - 7 } & $\begin{array}{r}\text { Agric \& } \\
\text { food }\end{array}$ & $\begin{array}{r}\text { All } \\
\text { merchan- } \\
\text { dise }\end{array}$ & Services & $\begin{array}{r}\text { Agric \& } \\
\text { food }\end{array}$ & $\begin{array}{r}\text { All } \\
\text { merchan- } \\
\text { dise }\end{array}$ & \\
& & & & & & \\
& & & & & & \\
& & & & & & \\
& -0.6 & -0.1 & 0.1 & 1.6 & -0.3 & -0.1 \\
South Africa & 2.6 & 1.4 & 1.3 & 1.5 & -0.6 & -0.1 \\
Other Southern Africa & -1.4 & -3.1 & -2.2 & 3.7 & -0.1 & -0.1
\end{tabular}

${ }^{a}$ Relative to the numeraire which in this version of the LINKAGE model is the price of high-income countries' exports of manufactures.

Source: Authors' World Bank LINKAGE model simulations 
Table 5: Regional and sectoral source of gains from full liberalization of global merchandise trade by developing and high-income countries, 2015

(Change in real income in 2015 relative to baseline scenario)

\begin{tabular}{|c|c|c|c|c|c|c|}
\hline & \multicolumn{3}{|c|}{ Gains by region in \$billion } & \multicolumn{3}{|c|}{ Percent of global ${ }^{\mathrm{a}}$ gain } \\
\hline & $\begin{array}{l}\text { Devel- } \\
\text { oping }\end{array}$ & $\begin{array}{l}\text { High- } \\
\text { income }\end{array}$ & World & $\begin{array}{l}\text { Devel- } \\
\text { oping }\end{array}$ & $\begin{array}{l}\text { High- } \\
\text { income }\end{array}$ & World $^{a}$ \\
\hline \multicolumn{7}{|l|}{ Developing countries liberalize: } \\
\hline Agriculture and food & 27 & 15 & 42 & 9 & 5 & $15(35)$ \\
\hline Textile and wearing apparel & 9 & 14 & 24 & 3 & 5 & $8(11)$ \\
\hline Other merchandise & 6 & 52 & 58 & 2 & 18 & $20(14)$ \\
\hline All sectors & 45 & 80 & 126 & 16 & 28 & $44(60)$ \\
\hline \multicolumn{7}{|l|}{ High-income countries liberalize: } \\
\hline Agriculture and food & 26 & 107 & 133 & 9 & 37 & $46(43)$ \\
\hline Textile and wearing apparel & 15 & 1 & 16 & 5 & 0 & $6(-0)$ \\
\hline Other merchandise & 4 & 5 & 9 & 1 & 2 & $3(-3)$ \\
\hline All sectors & 44 & 115 & 159 & 15 & 40 & $55(40)$ \\
\hline \multicolumn{7}{|l|}{ All countries liberalize: } \\
\hline Agriculture and food & 54 & 128 & 182 & 19 & 45 & $63(78)$ \\
\hline Textile and wearing apparel & 22 & 16 & 38 & 8 & 6 & $13(11)$ \\
\hline Other merchandise & 10 & 57 & 67 & 3 & 20 & $23(11)$ \\
\hline All sectors & 86 & 202 & 287 & 30 & 70 & $100(100)$ \\
\hline
\end{tabular}

${ }^{a}$ Numbers in parentheses are percentages of gains to Sub-Saharan Africa

Source: Authors' World Bank LINKAGE model simulations. 
Table 6: Impacts of full global merchandise trade liberalization on real value of agricultural and food exports and output, and on real net agricultural incomes, 2015

\begin{tabular}{|c|c|c|c|c|c|c|}
\hline & \multicolumn{2}{|c|}{ Ag \& food output } & \multicolumn{2}{|c|}{ Ag \& food exports } & \multicolumn{2}{|c|}{ Net farm income } \\
\hline & \$billion & Percent & \$billion $^{a}$ & Percent & \$billion & Percent \\
\hline High-income countries & -204.7 & -5 & $116(-90)$ & 16 & -64.8 & -17 \\
\hline Developing countries & 66.8 & 2 & $192(90)$ & 67 & 57.4 & 5 \\
\hline Sub Saharan Africa & 2.6 & 2 & $16(27)$ & 48 & 5.9 & 9 \\
\hline South Africa & 1.4 & 5 & $2(3)$ & 56 & 0.8 & 16 \\
\hline Other Southern Africa & 5.3 & 9 & $5(10)$ & 50 & 1.8 & 11 \\
\hline Rest of Sub-Saharan Africa & -4.1 & -1 & $10(14)$ & 45 & 3.3 & 8 \\
\hline World total & -137.8 & -1 & $308(0)$ & 36 & -7.4 & -0 \\
\hline
\end{tabular}

${ }^{a}$ Exports net of imports shown in parentheses

Source: Authors' World Bank LINKAGE model simulations. 
Table 7: Agricultural output and employment growth under different scenarios, 2004-2015

(annual percent growth rate between 2004 and 2015)

\begin{tabular}{lccc}
\hline & Baseline & Global & Doha Scenario 2 \\
\hline (a) farm output growth & & & \\
Sub-Saharan Africa & $\mathbf{4 . 5}$ & $\mathbf{4 . 9}$ & $\mathbf{4 . 7}$ \\
South Africa & 2.5 & 3.3 & 2.6 \\
Other Southern Africa & 5.3 & 5.7 & 5.4 \\
Rest of Sub-Saharan Africa & 4.6 & 4.8 & 4.8 \\
& & & \\
(b) farm employment growth & & & 2.4 \\
Sub-Saharan Africa & $\mathbf{2 . 3}$ & $\mathbf{2 . 6}$ & 0.1 \\
South Africa & 0.0 & 0.8 & 3.0 \\
Other Southern Africa & 3.0 & 3.3 & 2.3 \\
Rest of Sub-Saharan Africa & 2.2 & 2.5 & \\
\hline
\end{tabular}


Table 8: Agriculture and food's share of total GDP, and the share of its output that is exported, 2001 and 2015

\begin{tabular}{|c|c|c|c|c|}
\hline \multicolumn{5}{|l|}{ (percent) } \\
\hline & $\begin{array}{l}\text { Baseline } \\
2001\end{array}$ & Baseline & $\begin{array}{l}\text { Full lib’n } \\
2015\end{array}$ & $\begin{array}{r}\text { Doha } \\
\text { Scenario } 2\end{array}$ \\
\hline \multicolumn{5}{|c|}{ (a) Agric and food's share of GDP } \\
\hline High-income countries & 4.3 & 3.4 & 3.2 & 3.3 \\
\hline Developing countries & 16.9 & 16.1 & 16.5 & 16.3 \\
\hline Sub-Saharan Africa & 21.4 & 20.8 & 21.6 & 21.1 \\
\hline South Africa & 7.9 & 6.8 & 7.4 & 6.9 \\
\hline Other Southern Africa & 34.7 & 33.1 & 36.0 & 33.7 \\
\hline Rest of Sub-Saharan Africa & 27.0 & 26.6 & 26.9 & 26.9 \\
\hline World total & 6.7 & 6.2 & 6.1 & 6.2 \\
\hline \multicolumn{5}{|c|}{ (b) Share of ag and food output exported } \\
\hline \multirow{2}{*}{$\begin{array}{l}\text { High-income countries } \\
\text { (excluding intra-EU25 trade) }\end{array}$} & 11.1 & 12.3 & 14.8 & 12.5 \\
\hline & 5.8 & 7.5 & 11.6 & 8.2 \\
\hline Developing countries & 7.5 & 6.9 & 11.6 & 7.8 \\
\hline Sub-Saharan Africa & 12.5 & 15.8 & 23.1 & 16.6 \\
\hline South Africa & 16.0 & 12.7 & 18.8 & 13.5 \\
\hline Other Southern Africa & 13.2 & 18.1 & 25.4 & 19.2 \\
\hline Rest of Sub-Saharan Africa & 11.2 & 15.8 & 23.3 & 16.5 \\
\hline $\begin{array}{l}\text { World total } \\
\text { (excluding intra-EU25 trade) }\end{array}$ & $\begin{array}{r}9.5 \\
6.6\end{array}$ & $\begin{aligned} 9.5 \\
7.2\end{aligned}$ & $\begin{array}{c}\mathbf{1 3 . 2} \\
11.6\end{array}$ & $\begin{array}{l}\mathbf{1 0 . 0} \\
8.0\end{array}$ \\
\hline Source: Authors' World Bank LiN & nodel simu & & & \\
\hline
\end{tabular}


Table 9: Impacts of full global merchandise trade liberalization on real factor returns, $\mathbf{2 0 1 5}^{\mathrm{a}}$

(Percent change in real factor prices relative to the baseline in 2015)

\begin{tabular}{lrrrrr}
\hline & $\begin{array}{r}\text { Unskilled } \\
\text { wages }\end{array}$ & $\begin{array}{r}\text { Skilled } \\
\text { wages }\end{array}$ & Capital & $\begin{array}{r}\text { Farm } \\
\text { land }\end{array}$ & CPI \\
\hline & & & & & \\
South Africa & 2.8 & 2.5 & 1.8 & 5.7 & -1.6 \\
Other Southern Africa & 6.0 & 1.6 & 0.0 & 4.6 & 0.4 \\
Rest of Sub-Saharan Africa & 8.2 & 6.5 & 2.2 & 5.2 & -5.0 \\
\hline
\end{tabular}

a. Nominal factor prices are deflated by the consumer price index (CPI).

Source: World Bank LiNKAGE model simulations. 


\section{Table 10: Agricultural weighted average import tariffs, by region, 2001}

(percent, ad valorem equivalent, weights based on imports)

Bound tariff $\quad$ MFN applied tariff $\quad$ Actual applied tariff $^{\mathrm{a}}$

\begin{tabular}{|c|c|c|c|}
\hline Developed countries & 27 & 22 & 14 \\
\hline Developing countries & 48 & 27 & 21 \\
\hline of which: South Africa & 52 & 14 & 13 \\
\hline SSA LDCs & 63 & 15 & 13 \\
\hline Other SSA & 105 & 27 & 26 \\
\hline WORLD & 37 & 24 & 17 \\
\hline
\end{tabular}

Source: Jean, Laborde and Martin (2005, Table 3.2). 
Table 11: Average applied tariffs for all goods, by country/region, 2015 baseline and under various partial Doha reform scenarios

\begin{tabular}{|c|c|c|c|c|}
\hline \multicolumn{5}{|c|}{ (a) Agricultural and food tariffs (\%) } \\
\hline & Baseline & $\begin{array}{r}\text { Doha } \\
\text { Scenario } 1\end{array}$ & $\begin{array}{r}\text { Doha } \\
\text { Scenario } 2\end{array}$ & $\begin{array}{r}\text { Doha } \\
\text { Scenario } 3\end{array}$ \\
\hline South Africa & 8.6 & 8.1 & 8.1 & 6.6 \\
\hline Other Southern Africa & 11.8 & 11.6 & 11.5 & 11.0 \\
\hline Rest of Sub-Saharan Africa & 21.2 & 19.6 & 19.6 & 16.1 \\
\hline All developing countries & 14.2 & 12.5 & 12.4 & 10.6 \\
\hline High-income countries & 15.9 & 8.4 & 8.2 & 7.5 \\
\hline \multicolumn{5}{|c|}{ (b) Textile and clothing tariffs (\%) } \\
\hline South Africa & 21.9 & 21.9 & 17.4 & 13.2 \\
\hline Other Southern Africa & 12.5 & 12.5 & 12.4 & 12.2 \\
\hline Rest of Sub-Saharan Africa & 26.2 & 26.2 & 25.9 & 24.6 \\
\hline All developing countries & 14.3 & 14.3 & 12.7 & 11.3 \\
\hline High-income countries & 7.3 & 7.3 & 4.1 & 4.1 \\
\hline \multicolumn{5}{|c|}{ (c) Other merchandise tariffs (\%) } \\
\hline South Africa & 5.4 & 5.4 & 5.1 & 4.2 \\
\hline Other Southern Africa & 7.5 & 7.5 & 7.3 & 7.4 \\
\hline Rest of Sub-Saharan Africa & 14.0 & 14.0 & 14.0 & 13.7 \\
\hline All developing countries & 7.1 & 7.1 & 6.4 & 5.9 \\
\hline High-income countries & 1.2 & 1.2 & 0.8 & 0.8 \\
\hline \multicolumn{5}{|c|}{ (d) All merchandise trade tariffs (\%) } \\
\hline South Africa & 6.6 & 6.5 & 6.0 & 4.9 \\
\hline Other Southern Africa & 8.5 & 8.5 & 8.3 & 8.2 \\
\hline Rest of Sub-Saharan Africa & 16.3 & 16.0 & 15.9 & 15.0 \\
\hline All developing countries & 8.4 & 8.2 & 7.5 & 6.8 \\
\hline High-income countries & 2.9 & 2.3 & 1.6 & 1.6 \\
\hline
\end{tabular}

Source: Anderson, Martin and van der Mensbrugghe (2005a, Tables A12.10) 
Table 12: Change in real income in alternative Doha scenarios compared with full liberalization, 2015

\begin{tabular}{|c|c|c|c|c|}
\hline & $\begin{array}{r}\text { Doha } \\
\text { Scenario } 1 \\
\end{array}$ & $\begin{array}{r}\text { Doha } \\
\text { Scenario } 2 \\
\end{array}$ & $\begin{array}{r}\text { Doha } \\
\text { Scenario } 3 \\
\end{array}$ & $\begin{array}{r}\text { Full } \\
\text { liberaliz'n }\end{array}$ \\
\hline \multicolumn{5}{|c|}{$\begin{array}{l}\text { (a) in } 2001 \text { \$billion compared to } \\
\text { baseline }\end{array}$} \\
\hline High-income countries & 65.6 & 79.9 & 96.4 & 202 \\
\hline Developing countries & 9.0 & 16.1 & 22.9 & \\
\hline Sub Saharan Africa & 0.3 & 0.4 & 1.2 & 4.8 \\
\hline South Africa & 0.1 & 0.4 & 0.7 & 1.3 \\
\hline Other Southern Africa & 0.1 & 0.1 & 0.2 & 1.0 \\
\hline Rest of Sub-Saharan Africa & 0.0 & -0.1 & 0.3 & 2.5 \\
\hline World total & 74.5 & 96.1 & 119.3 & 287 \\
\hline \multicolumn{5}{|c|}{$\begin{array}{l}\text { (b) percent change compared to } \\
\text { baseline }\end{array}$} \\
\hline High-income countries & 0.20 & 0.25 & 0.30 & 0.6 \\
\hline Developing countries & 0.09 & 0.16 & 0.22 & 0.8 \\
\hline Sub Saharan Africa & 0.06 & 0.10 & 0.27 & 1.1 \\
\hline South Africa & 0.06 & 0.25 & 0.49 & 0.9 \\
\hline Other Southern Africa & 0.21 & 0.19 & 0.26 & 1.5 \\
\hline Rest of Sub-Saharan Africa & 0.02 & -0.02 & 0.13 & 1.1 \\
\hline World total & 0.18 & 0.23 & 0.28 & 0.7 \\
\hline Source: Authors' World Bank & ons. & & & \\
\hline
\end{tabular}


Table 13: Change in SSA's merchandise export and import trade patterns due to Doha Scenario 2 and compared with full trade liberalization, 2015

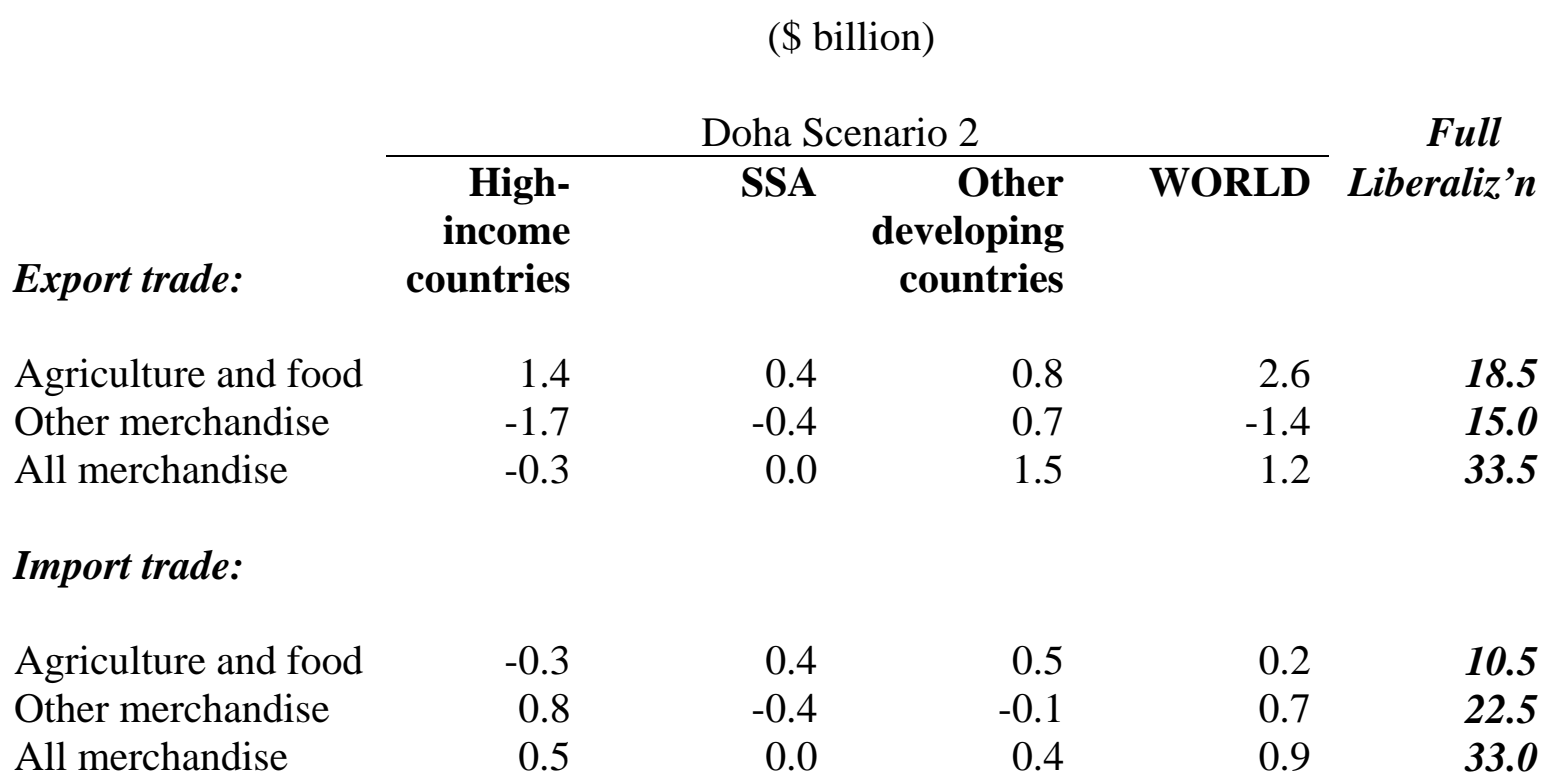

Source: Authors’ World Bank LiNKAGE model simulations 
Table 14: Domestic output, exports, absorption and self-sufficiency, Sub Saharan Africa, 2015

(Volume levels in 2015 in baseline, percent volume changes in 2015 in reform scenarios)

\begin{tabular}{|c|c|c|c|c|c|c|c|c|c|c|c|c|}
\hline & & $\begin{array}{l}\text { seline Ie } \\
\text { \$million }\end{array}$ & els in 20 & $\begin{array}{c}\text { Index } \\
\text { of }\end{array}$ & $\begin{array}{r}\mathbf{E} \\
(\mathrm{pe}\end{array}$ & $\begin{array}{l}\text { ects of } \\
\text { cent cha } \\
\text { baselir }\end{array}$ & $\begin{array}{l}\text { I liberaliz } \\
\text { e from }\end{array}$ & $\begin{array}{l}\text { tion } \\
\text { Index } \\
\text { of }\end{array}$ & $\begin{array}{r}\text { Ef } \\
\text { (per }\end{array}$ & $\begin{array}{l}\text { cts of D } \\
\text { ent chan } \\
\text { baseline }\end{array}$ & $\begin{array}{l}\text { ha Scena } \\
\text { from }\end{array}$ & $\begin{array}{l}2 \\
\text { Index } \\
\text { of }\end{array}$ \\
\hline & Output & Exports & $\begin{array}{l}\text { Domestic } \\
\text { Consump. }\end{array}$ & Self-suff. & Output & Exports & $\begin{array}{l}\text { Domestic } \\
\text { Consump. }\end{array}$ & Self-suff. & Output & Exports & $\begin{array}{l}\text { Domestic } \\
\text { Consump. }\end{array}$ & Self-suff. \\
\hline Rice & 16,283 & 186 & 17,949 & 91 & -21.5 & 39.1 & -8.9 & 78 & 0.4 & -6.6 & 0.1 & 91 \\
\hline Wheat & 1,910 & 68 & 3,601 & 53 & -37.0 & 149.7 & -5.6 & 35 & 5.2 & 15.6 & -0.1 & 56 \\
\hline Other grains & 13,134 & 399 & 12,985 & 101 & -0.8 & 44.1 & -1.6 & 102 & 0.3 & 5.3 & 0.0 & 101 \\
\hline Oil seeds & 3,031 & 1,198 & 1,918 & 158 & 79.1 & 198.5 & 1.6 & 279 & 7.0 & 17.1 & 0.4 & 168 \\
\hline Sugar & 13,014 & 1,808 & 11,984 & 109 & 6.3 & 108.5 & -0.1 & 116 & 14.9 & 95.2 & 2.1 & 122 \\
\hline Plant-based fibers & 4,962 & 3,863 & 1,287 & 385 & 52.8 & 72.9 & -15.2 & 694 & 16.9 & 21.9 & -0.7 & 454 \\
\hline Vegetables and fruits & 16,307 & 4,949 & 11,892 & 137 & 2.3 & 20.8 & -0.5 & 141 & -4.9 & -15.5 & 0.2 & 130 \\
\hline Other crops & 32,126 & 14,197 & 19,232 & 167 & 2.6 & 10.7 & -1.8 & 174 & -1.9 & -4.4 & 0.1 & 164 \\
\hline Livestock & 33,402 & 1,620 & 32,429 & 103 & 6.2 & 15.7 & 6.5 & 103 & 2.4 & -3.6 & 2.7 & 103 \\
\hline Other natural resources & 34,469 & 7,677 & 27,619 & 125 & 0.2 & 2.9 & -0.2 & 125 & -1.2 & -4.8 & -0.3 & 124 \\
\hline Fossil fuels & 51,738 & 25,673 & 35,302 & 147 & 9.2 & 26.4 & 3.9 & 154 & 0.0 & 0.1 & 0.1 & 146 \\
\hline Vegetable oils and fats & 4,620 & 489 & 5,416 & 85 & -14.8 & -22.7 & 0.8 & 72 & -1.1 & -13.7 & 0.3 & 84 \\
\hline Dairy products & 3,728 & 223 & 5,049 & 74 & 2.5 & 114.6 & -3.0 & 78 & 10.7 & 70.5 & -2.5 & 84 \\
\hline Other food, beverages and tobacco & 78,640 & 8,294 & 78,413 & 100 & -6.6 & 14.0 & 1.1 & 93 & -0.5 & -3.6 & 0.5 & 99 \\
\hline Textile & 16,143 & 2,871 & 21,453 & 75 & -19.3 & 8.0 & -1.3 & 62 & -3.3 & -8.6 & -0.7 & 73 \\
\hline Wearing apparel & 4,737 & 1,326 & 6,073 & 78 & -9.1 & 44.6 & 14.2 & 62 & -0.6 & 0.8 & 0.7 & 77 \\
\hline Leather & 4,440 & 874 & 5,243 & 85 & -29.8 & -4.8 & 1.1 & 59 & -3.8 & -7.7 & -0.2 & 82 \\
\hline Chemicals rubber and plastics & 32,943 & 6,583 & 46,956 & 70 & -4.2 & 22.3 & 1.7 & 66 & -1.2 & -4.1 & 0.1 & 69 \\
\hline Iron and steel & 8,639 & 4,435 & 9,171 & 94 & -0.2 & 6.2 & 0.7 & 93 & 0.6 & 1.1 & -0.3 & 95 \\
\hline Motor vehicles and parts & 12,486 & 3,739 & 21,372 & 58 & 27.8 & 144.1 & 9.4 & 68 & 3.0 & 7.3 & 0.8 & 60 \\
\hline Capital goods & 29,214 & 14,069 & 64,220 & 45 & 1.9 & 11.6 & 2.6 & 45 & 0.0 & 0.0 & 0.1 & 45 \\
\hline Other manufacturing & 98,868 & 35,055 & 86,303 & 115 & -4.9 & 7.0 & 0.7 & 108 & -1.6 & -3.4 & -0.2 & 113 \\
\hline Construction & 58,923 & 308 & 58,911 & 100 & 2.9 & 14.4 & 2.9 & 100 & 0.1 & -0.6 & 0.2 & 100 \\
\hline Utilities and services & 411,242 & 25,806 & 413,333 & 99 & 0.4 & 5.0 & -0.1 & 100 & 0.0 & -0.5 & 0.1 & 99 \\
\hline
\end{tabular}

Source: Authors’ World Bank LinKAGE model simulations 
Table 15: Changes in poverty ( those earning $<\$ 1 /$ day) in alternative Doha scenarios compared with full liberalization, 2015

\begin{tabular}{|c|c|c|c|c|c|}
\hline \multirow{2}{*}{2015 Headcount (\%) } & $\begin{array}{l}\text { Base } \\
\text { line }\end{array}$ & Full liberalization & $\begin{array}{c}\text { Doha } \\
\text { Scenario } 1\end{array}$ & $\begin{array}{l}\text { oha alternat } \\
\text { Doha } \\
\text { Scenario } 2\end{array}$ & $\begin{array}{c}\text { Doha } \\
\text { Scenario } 3\end{array}$ \\
\hline & & & & & \\
\hline East Asia \& Pacific & 0.9 & 0.8 & 0.9 & 0.9 & 0.9 \\
\hline Latin America \& Carib. & 6.9 & 6.6 & 6.9 & 6.9 & 6.8 \\
\hline South Asia & 12.8 & 12.5 & 12.8 & 12.7 & 12.6 \\
\hline Sub-Saharan Africa & 38.4 & 36.0 & 38.4 & 38.3 & 38.1 \\
\hline All developing countries & 10.2 & 9.7 & 10.2 & 10.2 & 10.1 \\
\hline 2015 Headcount & $\begin{array}{l}2015 \\
\text { level }\end{array}$ & $\begin{array}{l}\text { Decrease from baseline } \\
\text { in millions }\end{array}$ & \multicolumn{3}{|c|}{ Decrease from baseline in millions } \\
\hline East Asia \& Pacific & 19 & 2.2 & 0.1 & 0.3 & 0.5 \\
\hline Latin America \& Carib. & 43 & 2.1 & 0.3 & 0.4 & 0.5 \\
\hline South Asia & 216 & 5.6 & 0.2 & 1.4 & 3.0 \\
\hline Sub-Saharan Africa & 340 & 21.1 & -0.1 & 0.5 & 2.2 \\
\hline All developing countries & 622 & 31.9 & 0.5 & 2.5 & 6.3 \\
\hline
\end{tabular}


Table A: Impacts on real incomes of full liberalization of global merchandise trade, by country/region, base case in 2015 versus comparative static cases in 2001 (Change in real income, \$billion)

\begin{tabular}{|c|c|c|c|c|c|}
\hline & \multirow{2}{*}{$\begin{array}{c}2015 \\
\text { Base } \\
\text { case }\end{array}$} & \multicolumn{4}{|c|}{2001} \\
\hline & & $\begin{array}{r}\text { Scaled } \\
\text { dynamics } \\
\end{array}$ & $\begin{array}{r}\text { Comparative } \\
\text { static } \\
\end{array}$ & $\begin{array}{r}\text { GTAP } \\
\text { elasticities }\end{array}$ & $\begin{array}{r}\text { GTAP elas+ } \\
\text { fixed land } \\
\end{array}$ \\
\hline Australia and New Zealand & 6.1 & 3.5 & 2.2 & 1.8 & 1.7 \\
\hline EU 25 plus EFTA & 65.2 & 45.3 & 44.0 & 32.9 & 30.2 \\
\hline United States & 16.2 & 9.8 & 4.1 & 4.5 & 5.2 \\
\hline Canada & 3.8 & 2.5 & 2.1 & 1.0 & 0.8 \\
\hline Japan & 54.6 & 28.0 & 30.8 & 25.1 & 25.3 \\
\hline Korea and Taiwan & 44.6 & 14.3 & 16.1 & 8.9 & 9.1 \\
\hline Hong Kong and Singapore & 11.2 & 5.6 & 4.3 & 3.7 & 3.6 \\
\hline Argentina & 4.9 & 2.9 & 1.7 & 1.1 & 0.8 \\
\hline Bangladesh & 0.1 & 0.1 & -0.2 & -0.3 & -0.4 \\
\hline Brazil & 9.9 & 6.1 & 4.7 & 5.0 & 2.2 \\
\hline China & 5.6 & 1.9 & 0.6 & -0.5 & -2.5 \\
\hline India & 3.4 & 1.7 & -0.8 & -1.5 & -0.8 \\
\hline Indonesia & 1.9 & 1.0 & 0.2 & 0.1 & -0.1 \\
\hline Thailand & 7.7 & 3.7 & 2.1 & 1.4 & 0.9 \\
\hline Vietnam & 3.0 & 1.6 & 1.1 & 0.7 & 0.7 \\
\hline Russia & 2.7 & 1.4 & 2.0 & 1.6 & 1.4 \\
\hline Mexico & 3.6 & 2.3 & -0.4 & -1.5 & -1.5 \\
\hline South Africa & 1.3 & 0.8 & 0.7 & 0.5 & 0.4 \\
\hline Turkey & 3.3 & 1.7 & 1.3 & 0.9 & 0.9 \\
\hline Rest of South Asia & 1.0 & 0.5 & -0.2 & -0.3 & -0.3 \\
\hline Rest of East Asia & 5.3 & 2.7 & 2.9 & 2.0 & 1.7 \\
\hline Rest of LAC & 10.3 & 6.6 & 2.0 & -0.6 & -2.1 \\
\hline Rest of ECA & 1.0 & 0.3 & 0.6 & -0.2 & -0.4 \\
\hline Middle East and North Africa & 14.0 & 8.1 & 3.8 & 2.2 & 1.6 \\
\hline Selected SSA countries & 1.0 & 0.6 & 0.3 & 0.4 & 0.3 \\
\hline Rest of Sub Saharan Africa & 2.5 & 1.4 & -0.2 & -0.6 & -0.8 \\
\hline Rest of the World & 3.4 & 1.6 & 1.4 & 0.4 & 0.0 \\
\hline High-income countries & 201.6 & 109.8 & 103.7 & 77.9 & 75.8 \\
\hline Developing countries & 85.7 & 43.9 & 23.7 & 10.6 & 2.0 \\
\hline East Asia and Pacific & 23.5 & 9.4 & 6.9 & 3.7 & 0.6 \\
\hline South Asia & 4.5 & 2.2 & -1.2 & -2.1 & -1.5 \\
\hline Europe and Central Asia & 7.0 & 3.5 & 3.9 & 2.3 & 1.9 \\
\hline Middle East and North Africa & 14.0 & 8.1 & 3.8 & 2.2 & 1.6 \\
\hline Sub Saharan Africa & 4.8 & 2.8 & 0.7 & 0.2 & -0.1 \\
\hline Latin America and the Caribbean & 28.7 & 17.9 & 8.1 & 4.0 & -0.5 \\
\hline World total & 287.3 & 156.4 & 127.4 & 88.5 & 77.8 \\
\hline
\end{tabular}

a The scaled dynamic results refer to the impact of global merchandise trade reform with limited reductions in some key agricultural sectors in Japan (rice and sugar) and Korea and Taiwan (rice, oil seeds and other grains). The percentage change in real income in each region in 2015 resulting from the dynamic simulation is scaled to the 2001 level of income for that region.

Source: Authors' World Bank LiNKAGE model simulations. 